\title{
Deradicalisation Crime Of Terrorism Actors By Police (Case Study In Police Jurisdiction Of Semarang)
}

\author{
Bagus Gani Setiana ${ }^{1}$ and Sri Kusriyah ${ }^{2}$
}

Abstract. The paper titled "Deradicalisation Crime Of Terrorism Actors By Police", aims to identify and analyze the role of the National Police in the process of deradicalization of the criminal terrorism in Indonesia, the benefits of deradicalization, as well as the challenges and solutions faced by the National Police in the implementation of the deradicalization.

This study uses the Juridical Sociological Approach, with descriptive analysis models, which use the type and source of primary data that is the result of interviews with police personnel and ex-terrorist, as well as secondary data source that literature on the various sub - laws that exist in Indonesia. Also in this study, the authors also used the descriptive method of analysis. That in the end all results were analyzed by using the theory of Aristotle and theory of Justice usefulness of Jeremy Bentham.

Based on the research that has been analyzed, then it was concluded that the role of the National Police in deradicalizing the task is enormous, as evidenced by the reduction in the number of terrorism cases in Indonesia from year to year. In addition, the benefits of deradicalization can reduce the number of perpetrators of terrorism by changing the target ideology. But it is undeniable that the Police still face many obstacles, which in this study the authors provide some solutions to these obstacles.

Keywords: Deradicalisation; Ideology; Police; Terrorism.

\section{Introduction}

The events of terrorist bombings in Indonesia since 2002, has caused much loss of life and property. Concerns happens when religion is seen as a source of violence or used as a basis to justify terror against followers of other religions. Peace building can be done by promoting the spirit of tolerance, promoting peace, upholding human rights, and respect people of different faiths and different beliefs. ${ }^{3}$

To anticipate and address the issue of the crime of terrorism and in line and opening of the Constitution of 1945, the State of the Republic of Indonesia is a unitary state which is based on the law and have the duty and responsibility to maintain a safe, peaceful, and prosperous as well as participate actively maintaining world peace, the government must maintain and uphold the sovereignty and protect every citizen from every threat or destructive threats both domestic and abroad.

Based on the description above, the formulation of the problem in this research is: How is the role of the National Police in deradicalization efforts criminals of terrorism in the police jurisdiction of Semarang, as well as the challenges and solutions in the

1 Student of Master of Law, Universitas Islam Sultan Agung Semarang and Enterpreneur, email: bagusgani8@gmail.com

2 Faculty of Law Universitas Islam Sultan Agung

3 Djohan Effendi, 2012, Pesan-Pesan Al-Quran, Mencoba Mengerti Intisari Kitab Suci, Serambi, Jakarta, p. 73.

4 Elucidation: Government Regulation in Lieu of Law of the Republic of Indonesia Number 1 of 2002 on Combating Criminal Acts of Terrorism, 2003, Durat Bahagia, Jakarta, p. 32. 
implementation of the deradicalization?

\section{Research Methods}

This study uses the Juridical Sociological Approach. Types and Sources of Data includes Primary data is the Police Personnel who carry out the deradicalization program to potential terrorists, prisoners and former prisoners of terrorism in the locus of research; as well as secondary data namely Act No. 5 of 2018 on Amendments to the Act No. 15 of 2013 regarding the Stipulation of Government Regulation in lieu of Act No. 1 of 2002 on the Eradication of Terrorism Act, and other Police Regulation. Data collection methods include Study Library, Interview, and Observation.

\section{Results And Discussion}

\section{Police Role In The Effort Of Deradicalisation Terrorism Actors By Police In Police Jurisdiction Of Semarang}

\section{- Deradicalization activities undertaken by the police personnel of Semarang}

Bripka Dwi Susanto, who is a Bhabinkamtibmas personnel oversee a radical sensible called Mr. X directly by way of frequently visited his residence and shop, and discuss to discuss the problems of Religious. In addition Bripka Dwi Susanto efforts in carrying out the deradicalization is often invited $\mathrm{Mr}$. $\mathrm{X}$ to follow the nationalist religious activities, such as lectures held by Islamic religious leaders in Ambarawa, and often invite Mr. $X$ to meet and interact with the public, because of the nature closed owned by Mr. $\mathrm{X}$ is not because $\mathrm{Mr}$. $\mathrm{X}$ was once isolated in the place he lived, because he has a different view of other residents, the long beard and in their everyday wear clothing that is synonymous with terrorism, as well as reinforced with a wife who always use the veil every day. So Mr. $X$ became quite reclusive and rarely interact with citizens, which in the end Mr. X always learn something from what he saw on the internet and broadcast message that is not necessarily true. ${ }^{5}$

Some deradicalization efforts that up to this time are still performed by Bripka Dwi Susanto to $\mathrm{Mr}$. $\mathrm{X}$ and some other unforeseen at least can reduce their interest to undertake radical actions, though not yet able to understand the deadly ideology that is embedded in their minds.

Besides deradicalization activities are also held behind closed doors is carried out by the Police Security Intelligence personnel of Semarang Brigadier Krishna. Based on testimony of Brigadier Krishna, that specifically until now he has not found the Police Regulation and or regulation of the Head of Police Intelligence and Security Agency related to the deradicalization. Since it may be up to this time, the police are still focused on the activities of law enforcement against the perpetrators of terrorism, because it is the number of men who will and already carry out acts of terrorism more than the number of new people have the understanding radical, or also those who

\footnotetext{
${ }^{5}$ Results of interviews with Bhabinkamtibmas (Bhayangkara Pembina Keamanan dan Ketertiban Masyarakat/Bhayangkara Trustees of Security and Public Order) Police Ambarawa-Semarang, Bripka Dwi Susanto, SH held on Friday, December 21, 2018, at the police station in Ambarawa Jl. Pemuda No. 1 Ex. Panjang district. Ambarawa district. Semarang.
} 
have become ex terrorism. ${ }^{6}$

Broadly speaking, the deradicalization is an Intelligence operation, in other words those activities are closed, because the deradicalization is to change the ideology and mindset of the target, which can not be seen physically, because ideology and mindset are in the heart and brain of a human being, so it is not as easy implementation of deradicalization of existing theories. ${ }^{7}$ Brigadier Krishna explains, from heart to heart approach successfully implemented since Brigadier Krishna is able to carry out undercover properly, so that the target does not feel suspicious of him. Not responsibilities, even Brigadier Krishna never infiltrated into an inmate to get to know the target closer.

Brigadier Krishna did deradicalised by inserting understands and teachings of Islam according to the Quran and Hadith, as well as providing an understanding of the true Jihad in any talks at the moment they met. Goal formerly an ordinary person, then eventually became a terrorist because the process of brainwashing be structured by the terrorist network. Thus, in its handling, should be reconducted brainwashing but a more positive direction to be a good person like before becoming a terrorist.

The deradicalization efforts up to now are still performed by Brigadier Krishna, and the result is quite noticeably with the criminal attitude change that is more open to its surroundings, and began to find out about Islam more deeply, with the right teacher.

Ex Criminal explains the change in him gradually - gradually improving. Himself to be more open to people - people around, and more want to study Islam with the correct proposition, taught by teachers - teachers of Islamic religious leaders were proved correct. He did not think would attempt to deradicalization or any measure that happens to him, only that she felt was calmer now and live the life of society as men in general. $^{8}$

So the authors concluded that the deradicalization efforts that have been undertaken to Ex Criminal by Brigadier Krishna is successful, undetected by the target directly, as evidenced by changes in the target, according to which the flow to normal.

Deradicalization by personnel Bhabinkamtibmas when analyzed use Theory Justice of Aristotle, one of them is Communicative Justice. Deradicalisation remain to be implemented without reducing the sense of justice, because Bripka Dwi Susanto incarry out deradicalise open goals, and those goals even know if it is in the process of deradicalization or return of identity and ideology of radical ideology into nationalist ideology of Pancasila.

On the other hand, deradicalisation carried out by personnel of the Intelligence Police Police Semarang is closed, besides useful for deradicalization, but also aims to dismantle terrorist networks in Indonesia are scattered in some areas, although up to now has not found any network that acts in Semarang regency.

With the arrest of a terrorist mentioned above, it was legally upheld justice for the people of Indonesia. Terrorists convicted, then after going through various court

\footnotetext{
${ }^{6}$ Results of interviews with personnel Sat Intelkam Semarang Police Brigadier Krishna (alias). held on Saturday, December 22, 2018, held at Rumah Makan Godong Salam Ungaran.

7 Abdul Wahid, Kejahatan Terorisme Perspektif Agama, Ham, dan Hukum, 2004, Refika Aditama, Bandung.

${ }^{8}$ According to interviews with former prisoners Terrorism (Ex Napiter). which was held on Sunday December 23 2018, housed in the District. Of Semarang.
} 
proceedings, eventually detained at the Correctional Institution. This is when analyzed using Aristotle's theory of justice, can get into the Distributive Justice, Fairness and Justice Communicative Repair. Distributive justice against the perpetrators of terrorism, namely for his actions, which resulted in casualties and fear in the society, so that he must account for his actions to follow the judicial process in Indonesia until his sentence is completed.

- Deradicalisation compared with law enforcement efforts that have been implemented by Indonesian Police

Having carried out the research, then the writer gets comparison between the activities of law enforcement and deradicalization efforts against potential offenders, offenders and ex-offenders terrorism, which were summarized in the following table:

\begin{tabular}{|c|c|c|c|}
\hline No. & About & Law Enforcement & Deradicalisation \\
\hline 1 & Good result & $\begin{array}{l}\text { - Can provide a deterrent } \\
\text { effect for other perpetrators } \\
\text { of terrorism, so that the } \\
\text { number of terrorism cases } \\
\text { reduced } \\
\text { - Social justice for all } \\
\text { Indonesian people reached } \\
\text { with the prosecution of the } \\
\text { perpetrators of terrorism } \\
\text { - Feeling restless society } \\
\text { reduced somewhat } \\
\text { - Break the chain of terrorist } \\
\text { networks } \\
\text { - Reducing the number of } \\
\text { perpetrators of terrorism }\end{array}$ & $\begin{array}{l}\text { - Cells die terrorism by itself } \\
\text { - Disrupting terrorist networks } \\
\text { that are not connected to } \\
\text { each other } \\
\text { - Reducing the number of } \\
\text { investigators and } \\
\text { perpetrators of terrorism } \\
\text { - With accurate information } \\
\text { from the target, the police } \\
\text { can take action immediately } \\
\text { - The goal to be anti- } \\
\text { government } \\
\text { - Personal goal to be open in } \\
\text { the community } \\
\text { - Police task easier as aided by } \\
\text { the target }\end{array}$ \\
\hline 2 & Bad risult & $\begin{array}{l}\text { - Sympathizers / supporters } \\
\text { who feel sympathetic to the } \\
\text { accused, to be more eager to } \\
\text { commit terrorism for reasons } \\
\text { of solidarity } \\
\text { - Family terrorism iba be } \\
\text { thinking the same as the } \\
\text { investigator's } \\
\text { - Indonesian Police confronted } \\
\text { to Human Rights }\end{array}$ & $\begin{array}{l}\text { - Targets that failed ter } \\
\text { deradicalised back to the } \\
\text { terrorism network } \\
\text { - Target already know the } \\
\text { techniques of } \\
\text { deradicalization of the Police, } \\
\text { inform all members of the } \\
\text { network to be more vigilant } \\
\text { with Police } \\
\text { - Goal know the police } \\
\text { personnel who infiltrated } \\
\text { - The ideology of radical } \\
\text { increases targeted for } \\
\text { deradicalization which failed }\end{array}$ \\
\hline
\end{tabular}

Some of the benefits of deradicalization which the authors based on research results 
obtained in the field, among which:

- Breaking the chain of development of cells terrorism,

- Eliminating the radical ideology someone who is a gateway terrorism,

- Reducing the number of sympathizers of terrorism,

- Reducing the use of firearms as a last resort forced the Police in its efforts prone to human rights violations,

- Restoring life deradicalised targets like before becoming a terrorist,

- Provide a better future for the target of terrorism,

- As well as providing better security for the people of Indonesia.

Happiness according to the concept of Jeremy Bentham, if faced with a deradicalization activities, is an essential concept of happiness. ${ }^{9}$ How not, the perpetrators of terrorism who have successfully dideradikalisasi, happiness life was like before becoming a terrorist, then vowed to discard the ideology of radical and put an end to acts of terrorism, and the resulting events and terrorism cases in Indonesia is reduced, which will automatically bring happiness to the general public, which no longer feel threatened by terrorism, even for the National Police who was helped by the decreased number of terrorism in Indonesia.

\section{Closing}

\subsection{Conclusion}

From the results of the above research and analysis, then the writer gets the following conclusion:

- Police have a huge responsibility in reducing the number of terrorism in Indonesia. All the efforts have been carried out by the police, ranging from pre emtiv efforts, pre ventif, and repressive. Deradicalisation a pilot project current Police, carried out in general by all the police personnel, and exclusively by personnel Bhabinkamtibmas, Security Intelligence, and Densus 88 AT Police. The deradicalization be open and closed by the police personnel who manned, and have a common goal of reducing the number of terrorism in Indonesia.

- The benefits gained from the implementation of the deradicalization program of the police is very much in comparison with the efforts of law enforcement that has been done to date. Because the deradicalization of a preventive nature, has destroyed a great power because of terrorism disconnected directly from the roots.

\subsection{Suggestion}

Input for the success of deradicalization programs that have been and are being implemented, namely:

- Police in order to make specific operational guidelines and technical guidelines governing the deradicalization program.

- Police regularly in order to carry out the development of the ability to deradicalise education of the personnel.

- Police in order to more recruiting to personnel who are considered very capable of carrying out the deradicalization is closed, to perform the tasks of counter-radical.

\footnotetext{
${ }^{9}$ Saefudin Zuhri, Deradikalisasi Terorisme, 2017, Daulatpress, Jakarta.
} 
- In order Indonesian Police embrace the religious leaders, community leaders, and organizations that exist around its territory to be together with the Police Department do early prevention of terrorism, and spreading the ideology and teachings of the right to prevent understand radical is in the middle of society.

\section{Bibliography}

[1] Act No. 2 of 2002 on the Indonesian National Police.

[2] Act No. 5 of 2018 on Amendments to the Act No. 15 of 2013 regarding the Stipulation of Government Regulation in lieu of Act No. 1 of 2002 on the Eradication of Terrorism Act.

[3] Djohan Effendi, 2012, Pesan-Pesan Al-Quran, Mencoba Mengerti Intisari Kitab Suci, Serambi, Jakarta.

[4] Elucidation: Government Regulation in Lieu of Law of the Republic of Indonesia Number 1 of 2002 on Combating Criminal Acts of Terrorism, 2003, Durat Bahagia, Jakarta

[5] Prasetyo, Imam, "Selamat Menikmati Radikalisme, Kawan Semua", http://sejarah.kompasiana.com/2012/05/24/selamat-menikmati-radikalismekawan-semua/ (accessed October 30, 2018).

[6] Saefudin Zuhri, Deradikalisasi Terorisme, 2017, Daulatpress, Jakarta. 